удк 330.341.1:338.43

DOI https://doi.org/10.32851/2708-0366/2021.6.8

Ковтун В.A.

кандидат сільськогосподарських наук, доцент, доцент кафедри економіки та фонансів,

Херсонський державний аграрно-економічний університет

ORCID: https://orcid.org/0000-0002-4275-026X

Kovtun Valentyna

Kherson State Agrarian and Economic University

\title{
СТАН ТА ПЕРСПЕКТИВИ РОЗВИТКУ ІННОВАЦІЙНОЇ ДІЯЛЬНОСТІ СІЛЬСЬКОГОСПОДАРСЬКИХ ПІДПРИЄМСТВ
}

\section{STATE AND PROSPECTS OF DEVELOPMENT OF INNOVATIVE ACTIVITY OF AGRICULTURAL ENTERPRISES}

\begin{abstract}
Інновачійна діяльність сільськогосподарських підприємств спрямовується на пошук та реалізацію інноваційних проєктів, які забезпечать стабільний і прибутковий розвиток суб' скта господарювання в довгостроковій перспективі. Від сукупності внутрішніх $і$ зовнішніх умов залежить вибір інноваційної стратегіі, поточного стану та конкурентного середовища сільськогосподарського підприємства. В Украӥні розпочався новий етап розвитку сільського господарства, який характеризується збільшення обсягів використання інноваційних технологій. Проаналізовано особливості формування та використання певних інноваційних впроваджень у сучасних умовах. Встановлено, щуо ефективними для сільськогосподарських виробників є інноваційні платформи, які працюють у сфері big data такі продукти як: БАЙЕР БIЗНЕС ПЛЮС, АGRIANALYTICA, SAATВAU PROFIT MANAGER moųo.
\end{abstract}

Ключові слова: інновації, діяльність, стратегї, сільськогосподарські підприємства, інновачійні платформи, економічний ефект.

Инновационная стратегия деятельности аграрных предприятий направляется на поиск и реализацию инновационных проектов, которые обеспечат стабильное и прибыльное развитие предприятия в долгосрочной перспективе. От совокупности внутренних и внешних условий зависит выбор инновационной стратегии, текущего состояния и конкурентной среды сельскохозяйственного предприятия. В Украине начался новый этап развития сельского хозяйства, которыи характеризуется увеличение объемов использования инновационных технологий. Проанализированы особенности формирования и использования определенных инновационных внедрений в современных условиях. Установлено, что эффективными для аграриев есть инновационные платформы, которые работают в сфеpe big data такие продукты как: БАЙЕР БИЗНЕС ПЛЮС, AGRIANALYTICA, SAATВAU PROFIT MANAGER и тому подобное.

Ключевые слова: инновации, деятельность, стратегии, сельскохозяйственные предприятия, инновационные платформы, экономический эффект.

Agricultural production depends on natural and meteorological conditions. use of dimensional expensive equipment and the number of employees, and requires optimization of logistics, warehousing and monitoring of plants and animals. The innovation strategy of agricultural enterprises is aimed at finding and implementing innovative projects that will ensure stable and profitable development of the business entity in the long run. The choice of the strangest innovation strategy depends on the combination of internal and external conditions. The current state of the innovation of agricultural enterprises has been analyzed. There are several efficient logistic IT solutions, which provide optimal routes for picking and delivering finished products to customers. A new stage of agricultural development has begun in Ukraine, which is characterized by an increase in the use of innovative technologies. Peculiarities of formation and use of certain innovative implementations in modern conditions are analyzed. It has been established that innovative platforms operating in the field of big data such as: 
BAYER BUSINESS PLUS, AGRIANALYTICA, SAATBAU PROFIT MANAGER, etc. are effective for agricultural producers. We are promising for more effective monitoring of resources in the agricultural enterprises, Mobile ST, Mobile ST, Mobile ST, Mobile ST, etc. Programs GEO-Agro, GIS Panorama Farming, Farm Works Site (Pro), SST Summit, SMS Desktop Software (Advanced and Basic), JD Reports MAP, AgrarOfis, Agro-Net NG, FarmView Record Keeper people, kindly, to get rid of the plants, to secure the function of effective management of land, manufacturer, labor and financial resources of agricultural industrial enterprises. The importance of prospects for the development of an innovative strategy for agricultural enterprises and an effective mechanism for using innovative technological solutions to obtain economic and social effects are highlighted. It is established that in order to build a strategy for the development of innovative activities of agricultural enterprises should be improved legal and methodological framework, providing public and private investment funds.

Key words: innovations, activity, strategies, agricultural enterprises, innovation platforms, economic effect.

Постановка проблеми. Розвиток аграрного підприємства неможливий без впровадження стратегічних напрямів інноваційної діяльності. Інноваційні впровадження у аграрне виробництво у ринкових умовах $є$ вирішальним чинником ефективного розвитку й нарощування обсягів продукції. Вони зумовлюють якісні зміни технологій виробництва, в його структурі, переоцінку системи мотивації. Інноваційна стратегія ïx розвитку включає використання науково-технічних досягнень у сфері організації управління, техніки й технології та комплексний підхід до інноваційної діяльності.

Аналіз останніх досліджень і публікацій. Розвиток інноваційної діяльності сільськогосподарських підприємств $\epsilon$ актуальною серед науковців, таких як: В.Г. Андрійчук, В.Я. Амбросов, Н.О. Афендікова, В.О. Білінська, В.М. Гейц, А.А. Гребеннікова, О.І. Дацій, С.I. Дем'яненко, О.В. Кривешко, І.В Ксьонжик, М.М. Кулаєць, М.Й. Малік, А.В. Нелепова, Т.В. Писаренко, Т.Р. Побережна, П.Т. Саблук, П.В. Сідун, Н.М. Сіренко, Н.T. Тверезовська, С.I. Тищенко, О.I. Шаманська, О.Г. Шпикуляк тощо. Сільськогосподарським підприємствам необхідно активно шукати та впроваджувати високоякісні технології інноваційної діяльності , які здатні підвищити обсяг виробництва, переробки та реалізації продукції з високим економічним ефектом.

Формулювання цілей статті. Метою дослідження є аналіз сучасного стану інноваційної діяльності аграрних підприємств та перспективи впровадження новітніх інформаційних технологій і їх вплив на ефективне використання виробничо-ресурсного потенціалу. Виявити важливість розробки стратегії інноваційної діяльності та ефективний механізм використання інноваційних технологічних рішень для аграрних виробників.

Виклад основного матеріалу. У світовому бізнесі розвиток сільського господарства $є$ однією з найбільш перспективних сфер. Інноваційні стратегії базуються на оцінці стратегічних чинників зовнішнього та внутрішнього середовища. Вони впливають на процеси виробництва, основними з яких $є$ : організаційні особливості аграрних підприємств і стан аграрних ринків: можливість впровадження інноваційних технологій та конкурентна ситуація господарства; стан їх інвестиційної політики по виробництву, переробці, реалізації продукції. Аграрні підприємства України вивчають зарубіжний досвід та активно шукають шляхи впровадження високоякісні інноваційні рішення у своїх господарствах. Інноваційна діяльність цих підприємств дає можливість забезпечити конкурентоспроможність їх продукції як на вітчизняному, так і на світовому ринках. Вона $є$ вирішальним фактором соціально-економічного розвитку i розв'язання економічних, екологічних, соціальних та інших проблем сільських об'єднаних територіальних громад [1].

Сучасний стан розвитку інноваційної діяльності сільськогосподарських підприємств свідчить про недостатність використання інструментів інноваційного управління для економічної ефективності їх виробничо-ресурсного потенціалу. У аграрному виробництві відбуваються динамічні зміни, більшості підприємствам важко передба- 
чити стійкі конкурентні переваги свого майбутнього розвитку. Інноваційна діяльність $\epsilon$ ефективним інструментом вирішення проблем підвищення конкурентоспроможності сільськогосподарських підприємств і є ключовим напрямком стратегічного та тактичного управління підприємством.

Стратегічне управління інноваційною діяльністю аграрних підприємств спрямовується на пошук та реалізацію інноваційних проєктів, які забезпечать стабільний i прибутковий розвиток суб'єкта господарювання в довгостроковій перспективі. Вибір інноваційної стратегії залежить від базової стратегії підприємства, його поточного стану та конкурентного середовища. Для розвитку інноваційної діяльності сільського господарства головною стратегією є глобалізація, складовими якої є обов'язкові екологічні, технологічні компоненти та стратегія бізнес-планування. Основними напрямками стратегії інноваційного регіонального розвитку сільського господарства є: цільовий ринок, позиція та асортимент сільськогосподарської продукції, ціноутворення, реклама, стимулювання іiї переробки та збуту, тощо. Задачею розвитком інноваційної діяльності аграрних підприємств є зміни в техніці, технології, організації, екології, економіці, а також у соціальній сфері для одержання економічного ефекту, спрямованого на задоволення певних суспільних потреб. На авторському рисунку 1 відображено взаємозв'язок стратегії інноваційного діяльності з іншими стратегіями діяльності сільськогосподарських підприємств [2, с. 147].

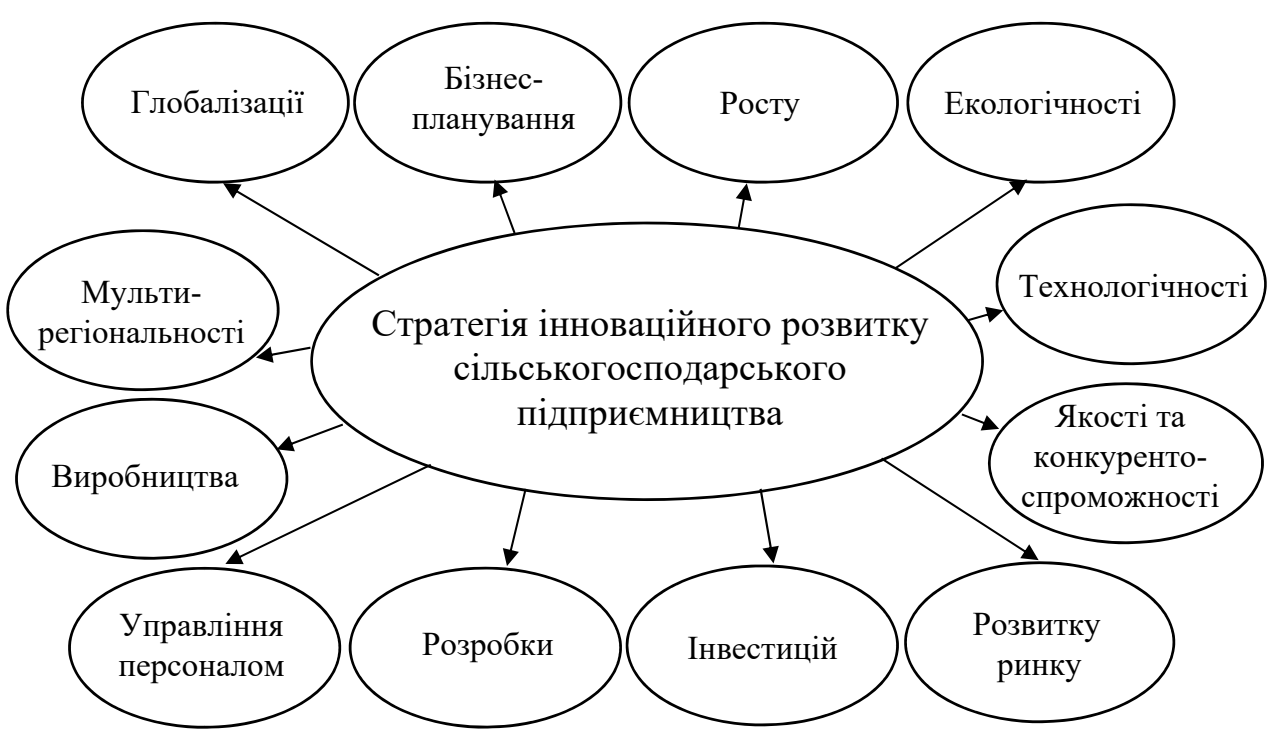

Рис. 1. Взаємозв'язок стратегії інноваційної діяльності з іншими стратегіями розвитку сільськогосподарських підприємств

Інноваційна діяльність у сільському господарстві - це комплексний процес створення нових культур із більш високою врожайністю сортів; виведення поголів'я худоби та виробництво елітного насіння; виготовлення високопродуктивних сільськогосподарських машин і агрегатів; впровадження прогресивних техніко-технологічних, організаційно-економічних й управлінських рішень; комерціалізація сучасних споживчих норм. Основу інноваційного потенціалу сільськогосподарського підприємства складають кадрові та матеріально-технічні складові та наявність науково-технічної й інтелектуальної власності. Щоб створити сприятливі умови для розвитку іннова- 
ційної діяльності аграрного бізнесу в Україні, потрібно ліквідувати його фінансову нестабільність, яка стримує залучення як вітчизняних так і зарубіжних фінансових інвесторів. Заходи щодо удосконалення законодавчої бази та фінансового оздоровлення сільськогосподарських підприємств повинні стати пріоритетними в державній аграрній політиці [3].

Стратегія інноваційного розвитку сільськогосподарських підприємств - це сукупність дій та методів ведення інноваційної діяльності, що має свою специфіку та забезпечує конкурентні переваги за рахунок інновацій. Головною метою державної інноваційної політики є створення соціально-економічних, організаційних і правових умов для ефективного відтворення, розвитку й використання науково-технічного потенціалу країни; забезпечення впровадження сучасних екологічно чистих, безпечних, енерго- та ресурсозберігаючих технологій; виробництва й реалізації нових видів конкурентоспроможної продукції.

Інноваційна стратегія розвитку сільськогосподарських підприємств передбачає системний підхід до освоєння інновацій. Інноваційний потенціал розглядається як: сукупність ресурсів, необхідних для здійснення інноваційної діяльності; сукупність активів, що використовуються в інноваційній діяльності; можливості підприємства, що визначають обсяги, терміни, кількість і якість його інноваційної діяльності; здатність підприємства проявляти інноваційну активність; міра готовності їх до здійснення інноваційної активності; складна динамічна система, що здійснює інноваційну діяльність; характеристика потоку нововведень; складова інтелектуального потенціалу та певна структура його складових; одна з трьох складових інноваційного простору. Вона $є$ складною динамічною системою генерування, накопичення і трансформування наукових, управлінських ідей та науково-технічних, маркетингових результатів і інноваційних продуктів на основі здійснення безперервного управління аграрним підприємством [4, с. 69].

Виділяють три стратегічні напрями ресурсно-технологічного оновлення сільського господарства: створення і застосування технологій і біоресурсів, що сприяють здешевленню вироблюваної продукції; розробка та впровадження технологій і біоресурсів, які дають можливість істотно підвищити якість продуктів харчування та аграрної сировини; створення та використання технологій і основних біологічних засобів виробництва, що забезпечують випуск екологічно чистого продовольства й екологічну аграрну діяльність, переробку її продукції [4, с. 18].

Для вдосконалення аграрної політики необхідним є врахування інноваційної компоненти, що дасть можливість посилити внутрішні індикатори господарської діяльності аграрних господарств на основі формування технологічних, агротехнічних та організаційно-економічними можливостей інноваційної діяльності. Однією із головних причин низької інноваційної активності вітчизняних аграрних підприємств $є$ відсутність механізмів та інструментів зацікавленості у впровадженні інноваційних розробок у сільськогосподарське виробництво [5, с. 33].

Перспективною $є$ концептуальна модель формування стратегії розвитку інноваційно-інвестиційного діяльності аграрних підприємств, де ключовою складовою є чітке формулювання та визначення цілей їх діяльності, що забезпечить формулювання інноваційних орієнтирів на різних їі стадіях. Модель цієї стратегії дасть можливість підвищити конкурентоспроможність продукції аграрних підприємств, забезпечити стійкі позиції на аграрному ринку та підвищити ефективність їх функціонування [6, с. 125].

Впровадження прогресивних ресурсозберігаючих і мінімальних технологій обробітку грунту (Mini-till, No-till або Zero-till та Strip-till) мають проблеми в адаптації до вітчизняних умов, це: слабка державна підтримку та фінансові витрати; необхідність заміни машинно-тракторного парку та традиційних технологій виробництва на сучасні інформаційні технології. Економічний ефект від запровадження мінімального 
обробітку грунту в 2020 році становитиме 6,3 млрд. грн. [7, с. 77]. Ефективність впровадження інноваційних агротехнічних заходів у рослинництві наведена в таблиці 1.

Таблиця 1

Ефективність впровадження пріоритетних заходів у рослинництві

\begin{tabular}{|c|c|c|c|}
\hline \multirow[t]{2}{*}{ Види заходів } & \multicolumn{2}{|c|}{ Роки } & \multirow{2}{*}{$\begin{array}{c}\text { Темп росту, } \\
\%\end{array}$} \\
\hline & 2015 & 2020 & \\
\hline \multicolumn{4}{|c|}{ Біологізація } \\
\hline Внесення органічних добрив, млн т забезпечить: & 57,9 & 105 & 181,3 \\
\hline - приріст гумусу, тис. т & 2606 & 4725 & 181,3 \\
\hline - надходження NPK, тис. т & 1186 & 2098 & 176,9 \\
\hline \multicolumn{4}{|c|}{ Запровадження науково-обгрунтованих сівозмін } \\
\hline -посіви багаторічних трав, млн га & 1,8 & $1, .9$ & 105,6 \\
\hline - бобових культур, млн га & 2,3 & 2,8 & 121,7 \\
\hline забезпечить: - щорічне утворення гумусу, тис. т & 3680 & 3760 & 102,2 \\
\hline - фіксації біологічного азоту, тис. т & 496 & 502 & 101,2 \\
\hline -економію мінеральних добрив, млн грн & 4960 & 5020 & 101,2 \\
\hline \multicolumn{4}{|c|}{ Розширення посівів сидеральних культур } \\
\hline Площа посівів, млн. га забезпечить: & 1,5 & 2,0 & 133,3 \\
\hline - утворення гумусу, тис. т & 1350 & 1800 & 133,3 \\
\hline - надходження NPK, тис. т & 251 & 342 & 136,2 \\
\hline - економію мінеральних добрив, млн грн & 1960 & 2620 & 133,7 \\
\hline \multicolumn{4}{|c|}{ Використання на добрива побічної продукції рослинництва } \\
\hline Обсяг побічної продукції, млн т забезпечить: & 28,8 & 37,5 & 130,2 \\
\hline - утворення гумусу, тис. т & 4296 & 5513 & 128,3 \\
\hline - надходження NPK, тис. т & 630 & 820 & 130,2 \\
\hline - економію мінеральних добрив, млн грн & 4920 & 6280 & 127,6 \\
\hline
\end{tabular}

Джерело: [7, с. 78]

Тваринництво, як основна галузь сільськогосподарського виробництва потребує значних інвестицій. Сучасний стан його розвитку знаходиться в кризовому стані. Необхідна кардинальна стимуляція суб'єктів господарювання цієї галуззі до модернізації, технологічної оснащеності та провадження інноваційних більш інтелектуальних рішень. Впровадження нових стратегічних рішень у розвиток тваринництва, при ефективному використанні ресурсного його потенціалу, можливості сучасних інформаційних систем дозволяють: підтримувати оптимальний мікроклімат у приміщеннях із тваринами; відстежувати динаміку їх здоров'я, приросту маси тварин та відповідності показників нормативним критеріям; автоматизувати планування структури стада; враховувати генеалогію та біологічні цикли при плануванні розмноження тварин; формувати автоматизовано раціон їх харчування та план ветеринарних заходів.

Суть інноваційних технологій у розвиток галуззі тваринництва - це впровадження, в першу чергу, біотехнологій із застосуванням методів клітинної та генної інженерії у підвищенні відтворювальних функцій тварин та в перспективі створення вітчизняного ринку племінних ресурсів, який би повністю забезпечив внутрішню потребу та орієнтувався на експорт. 
Стан техніко-технологічного забезпечення, що характеризується оновленням технологічної бази ферм новітнім обладнанням для утримання тварин в теперішніх умовах, досить слабкий. Перспективні та сучасні норми годівлі повинні враховувати потреби тварин в енергії, сухій речовині, протеїнах, вуглеводах, клітковині, жирі, мікроелементах, каротині, вітамінах методом створення різноманітних їх режимів стосовно відповідних порід тварин через точність їх дозування.

Впровадження ресурсозберігаючих технологій, що базуються на повній автоматизації процесу, використанні робототехніки, створенні кормової бази, розведенні високопродуктивного поголів'я відсутні, через нестачу організаційно-економічної, фінансової та матеріально-технічної підтримки. Основним завданням для галузі тваринництва, завдяки впровадженню інноваційних технологій, є збільшення виробництва валової продукції у 2020 році до 83,4 млрд грн, що майже в 2 рази більше 2010 року, а також збільшення обсягів виробництва м'яса в забійній масі у 2020 році до 4365 тис. т, або темп приросту цього показника буде становити 112,0\% [8].

Сільськогосподарським підприємствам в перспективі необхідний новий підхід до організації внутрішнього планування. Аналітичні системи вирішують такі питання як планування: оптимального розміщення рослин, чергування рослин в сівозмінах, можливості ущільнених посівів та посадок тощо. Електронний агрохімічний паспорт кожного поля може бути доступним у комп’ютерах чи на мобільному пристрої. Аналітичні системи дають можливість автоматичного розрахунку потреби в насінні, добривах та засобах захисту рослин, а також забезпечують функцію ефективного управління бюджетом господарства. Програми ГЕО-Агро, ГІС Панорама Землеробство, Farm Works Site (Pro), SST Summit, SMS Desktop Software (Advanced i Basic), JD Reports MAP, АграрОфic, Agro-Net NG, FarmView Record Keeper та інші дають можливість автоматичного розрахунку потреби в насінні, добривах та засобах захисту рослин, а також забезпечують функцію ефективного управління земельними, виробничими, трудовими та фінансовими ресурсами сільськогосподарських підприємств.

Для залучення іноземних інвесторів необхідним є бізнес-план, який повинен відповідати міжнародним стандартам і повинен бути адаптованим до сучасних умов України. В процесі бізнес-планування необхідно застосовувати програми Comfar (UNIDO), Project Expert, пакети компаній „ІНЕК” та „Альт-Інвест”, Project Manager, Success та інші. Сільськогосподарський сектор економіки України для впровадження інноваційних розробок потребує щорічних інвестицій не менше 75 млрд. грн. [9, с. 602].

Перспективне впровадження передових систем землекористування та новітніх сільськогосподарських технологій вимагають розробки, удосконалення та впровадження інноваційних інформаційних технологій. До таких систем можна віднести Global Positioning System (GPS), „Rapid Eye”, CORINE Land Cover (Coordination of Information on the Environment). Ефективними для діяльності сільськогосподарських підприємств $є$ інноваційні платформи, які працюють у сфері big data такі продукти як: БАЙЕР БІЗНЕС ПЛЮС, AGRIANALYTICA, SAATBAU PROFIT MANAGER тощо.

Перспективним, для більш ефективного використання ресурсів сільськогосподарських підприємств, є застосування смартфонів та мобільних додатків, які можуть здійснювати такі операції: відстежувати та контролювати транспортні засоби та здійснювати контроль за діяльністю водіїв; нагадувати та попереджати про необхідність здійснення операцій та застерігати про можливі критичні ситуації. Супровід і підтримку застосування смартфонів та мобільних додатків здійснюється через такі програми, як: ГЕО-Обліковець, ГЕОПлан, Кишеньковий вимірювач, Агронавт, Farm Works Mobile, SST Stratus, SMS Mobile, AGROGPS Mobilbox та інші.

Логістичні питання вирішуються за допомогою таких сервісів як Navizor.com, що аналізують розташування та відстань до збору врожаю, вантажомісткість тран- 
спортних засобів, маршрути доставки, максимальний час доставки продукції та якість дорожнього покриття. Система GPS-моніторингу дозволяе контролювати переміщення транспорту в режимі реального часу і вчасно реагувати на затримки чи відхилення від маршруту. Для розробки можливості вести контроль за витратою палива, дистанційно відстежувати діяльність техніки та вести контроль за площею, що обробляється використовуються GPS-трекінг техніки та лог-буки, які дозволяють проводити фото- та відео-фіксацію на місці роботи та негайне передавати файли до пункту адміністрування [8].

У перспективі поліпшення інноваційної діяльності через технологічні рішення дозволять: максимально зменшити залежність від природних умов, раціонально використовувати особливості погоди на користь розвитку рослин; автоматизувати систему поливу та ефективно використовувати поливну воду; планувати внесення добрив на підставі хімічного аналізу вмісту поживних речовин кожного поля; здійснювати моніторинг наявності шкідників та планувати внесення інсектицидів при перевищенні порогу їх шкодочинності тощо.

Висновки. Розробка програми інноваційного розвитку та відповідної стратегії $€$ базою формування конкурентних переваг і стійкого фінансового стану вітчизняних сільськогосподарських підприємств. Для прийняття у них раціональних стратегічних управлінських рішень для покращення їх інноваційного розвитку сучасні технології дозволять виявляти недоліки та ризики в технологічних процесах. Впроваджуючи в діяльність аграрних підприємств інноваційні технології, інвестиційні кошти працюють не тільки на стратегічні плани, а і на їх тактичні можливості, заощаджуючи земельні, виробничі, трудові та фінансові ресурси.

Правильно обрана інноваційна стратегія мобілізує ефективне використання науково-технічного, фінансово-економічного, соціального і організаційного потенціалу підприємства. Першочерговим завданням постає визначення пріоритетних напрямів розвитку підприємства, забезпечення конкурентоспроможності продукції та підвищення ефективності виробництва.

Перспективне впровадження стратегії інноваційного розвитку відкривають нові можливості для покращення економічної ефективності господарювання сільськогосподарських підприємств. Стратегія розвитку інноваційної діяльності підприємства повинна бути забезпечена удосконаленою правою та методичною базою, інвестиційними коштами для вибору оптимального варіанту інновацій, впровадження в діяльність підприємства, стабільність та інтенсивний тип розвитку цих суб'єктів господарювання.

\section{Список використаних джерел:}

1. The global innovation index 2017. Innovation feeding the world/Soumitra Dutta, Bruno Lanvin, and Sacha Wunsch-Vincent. URL: http://www.wipo.int/edocs/pubdocs/en/wipo pub gii 2017.pdf.

2. Ковтун В.А. Інноваційна стратегія розвитку аграрних підприємств. Фінпростір. 2020. № 3 (39). C. 142-153.

3. Тверезовська Н.T., Нєлепова А.В. Інформаційні технології в агрономії. 2017. URL: https://pidruchniki.com/1337101861366/informatika/rozvitok_vprovadzhennya_informatsiynih_ tehnologiy_silskomu_gospodarstvi.

4. Писаренко Т.В. Стан інноваційної діяльності та діяльності у сфері трансферу технологій в Україні у 2017 році : аналітична довідка. Київ : УкрIНTЕI, 2018. 98 с.

5. Афендікова Н.О. Інноваційний розвиток аграрного виробництва в сучасних умовах. Економіка та держава. 2016. № 6. С. 32-34.

6. Шаманська О.І. Формування системи інноваційно-орієнтованого розвитку аграрних підприємств. Ефективна економіка. 2016. № 12. С. 123-128.

7. Білінська В. Сучасні інноваційні технології в сільському господарстві: основна характеристика та перспективи впровадження. Вісник Київського наиіонального університету імені Тараса Шевченка. Економіка. 2015. Вип. 7 (172). С. 75-81. 
8. Ковтун В.А. Роль інтелектуальних технологічних рішень для ефективного використання ресурсів сільського господарства. Східна Європа: економіка, бізнес та управління. 2019. №1(18). URL: http://www.easterneurope-ebm.in.ua/18-2019-ukr.

9. Ковтун В.А. Стан та перспективи інвестиційного забезпечення галузі сільського господарства України. МНПІК. Сучасний рух науки, Way Science. Дніпро, 2018. С. 599-604.

\section{References:}

1. Dutta S., Lavnin B. \& Wunsch-Vincent S. (2017) The global innovation index 2017. Innovation feeding the world. Available at: http://www.wipo.int/edocs/pubdocs/en/wipo_pub_gii_2017.pdf.

2. Kovtun V.A. (2020). Innovatsiina stratehiia rozvytku ahrarnykh pidpryiemstv [Innovative strategy for the development of agricultural enterprises]. Finansovyi prostir [Financial space], no. 3, pp. 142-153. (in Ukrainian)

3. Tverezovska N.T., Nielepova A.V. (2017) Informatsiini tekhnolohii v ahronomii [Information technologies in agronomy]. Kyiv: Tsentr Uchbovoi Lit-Ry (in Ukrainian)

4. Pysarenko T.V. (2018) Stan innovatsiinoi diialnosti ta diialnosti u sferi transferu tekhnolohii v Ukraini u 2017 rotsi: analitychna dovidka [The state of innovation and technology transfer activities in Ukraine in 2017: an analytical reference] Kyiv: UkrINTEI. (in Ukrainian)

5. Afendikova N.O. (2016) Innovatsiinyi rozvytok ahrarnoho vyrobnytstva v suchasnykh umovakh [Innovative development of agricultural production in modern conditions]. Ekonomika ta derzha$v a$ [Economy and state], no. 6, pp. 32-34. (in Ukrainian)

6. Shamanska O.I. (2016) Formuvannia systemy innovatsiino-oriientovanoho rozvytku ahrarnykh pidpryiemstv [Formation of a system of innovation-oriented development of agricultural enterprises]. Efektyvna ekonomika [Efficient economy], no. 12, pp. 123-128. (in Ukrainian)

7. Bilinska V. (2015) Suchasni innovatsiini tekhnolohii v silskomu hospodarstvi: osnovna kharakterystyka ta perspektyvy vprovadzhennia [Modern innovative technologies in agriculture: main characteristics and prospects of implementation]. Visnyk Kyivskoho natsionalnoho universytetu imeni Tarasa Shevchenka. Ekonomika [Bulletin of the Taras Shevchenko National University of Kyiv. Economy], no. 7 (172), pp. 75-81. (in Ukrainian)

8. Kovtun V.A. (2019) Rol intelektualnykh tekhnolohichnykh rishen dlia efektyvnoho vykorystannia resursiv silskoho hospodarstva [The role of intelligent technological solutions for the efficient use of agricultural resources]. Skhidna Yevropa: ekonomika, biznes ta upravlinnia [Eastern Europe: Economy, Business and Management], no. 1(18). (in Ukrainian)

9. Kovtun V.A. (2018) Stan ta perspektyvy investytsiinoho zabezpechennia haluzi silskoho hospodarstva Ukrainy [Status and prospects of investment support of the agricultural sector of Ukraine]. Suchasnyi rukh nauky -The modern movement of science, Way Science, pp. 599-604. (in Ukrainian) 